\title{
How well do we know the issue of resilience? Literary research of current levels of knowledge
}

\author{
Jana OSTÁRKOVÁ*, Michaela STANÍČKOVÁ**
}

\begin{abstract}
Economies have always been sensitive to certain types of shocks in the past. This article deals with the growing importance of resilience and the development of this concept connected with regional development and emphasises its significance for the 4.0 generation and smart specialisation. In addition to the $4^{\text {th }}$ Industrial Revolution, it is necessary to mention the current topic, which is directly related to the concept of resilience and is, to some extent, behind its revival, i.e., COVID-19. Due to the COVID-19 crisis, the resilience topic is gaining prominence, and its importance is growing. The COVID-19 crisis shows how it has reduced the resilience of key systems to shocks and allowed failures to cascade from one system to others. A systemic approach based on resilience must be proposed to prepare socioeconomic systems for future shocks. The European Union is no exception and it must, therefore, accept strategies oriented on resilience.
\end{abstract}

Keywords: COVID-19, crisis, development, EU, industrial revolution, literary research, resilience, smart specialisation

\section{Introduction}

At the core of academic debates, the concept of resilience is also a hot topic for debates among politicians and the public. Resilience, which is mostly used to portray how an object or system reacts to some kind of endogenous or mostly exogenous shocks and disruptions, has been studied for a long time. Throughout time, efforts have been made to explore and to analyse its different aspects. The term resilience is usually used in studies in all scientific fields, from environmental studies, ecology, psychology, sociology and economics to materials science and engineering: consequently, the term is currently occurs in different contexts,

\footnotetext{
* Jana OSTÁRKOVÁ is PhD student at VSB-Technical University Ostrava, Ostrava, Czech Republic; e-mail: jana.ostarkova@ vsb.cz (ORCID 0000-0003-0984-5141).

** Michaela STANÍČKOVÁ is Associate Professor at VSB-Technical University Ostrava, Ostrava, Czech Republic; e-mail: michaela.stanickova@vsb.cz (corresponding author, ORCID 0000-0001-6210-2377).
} 
particularly when the desired element or feature of an object, entity or system needs to be promoted or supported in one way or another (Martin and Sunley, 2015). As a result of the changes that have taken place in recent years, which have influenced all parts of the regional economy and which were caused by the global economic crisis, the concept and idea of resilience are becoming increasingly important in economic geography and regional studies. The challenge of resisting economic fluctuations is faced not only by the economies of individual countries, but also by their regions, not only in terms of length of the crisis but also in terms of dramatic change and complexity.

In line with the ongoing importance of the region as an economic subject and matter of decision-making procedures in regional issues of public policies, mainly based on the principle of subsidiarity, the concept of resilience became a part in the regional economic studies' aim after the economic crisis of 2007-2009. Following this fact, there is growing attention paid to the resilience of regional, local and urban economies; attention is also paid to this concept at the city level. Scientists are more interested in regional resilience research (Martin, 2012; Rose, 2009; Cutter et al., 2008; Hill et al., 2008; Norris et al., 2008; Foster, 2006). Resilience is generally defined in these studies as the ability of a region or system to respond to endogenous or exogenous shocks or disruptions and of ensuring its ongoing development in such circumstances. Considering the factors mentioned above, we can assume that due to the recent and ongoing pandemic crisis, which has become a recent example of a global problem, the concept of the resilience of regions and countries will be a top priority in future policymaking. However, it is necessary to emphasise the paradox that occurs here: the pressure to use the concept of regional economic resilience (at any regional level) in political circles is somewhat ahead of the very understanding of the concept of resilience. In addition, it should be noted that the concept of resilience is also the subject of measurement and evaluation from a theoretical (finding methodology) and practical (application) point of view. In the context of regional development, there is currently no generally agreed upon notion of resilience, nor is there a clear consensus on what precisely is meant by regional economic resilience and the way it should be launched. Simultaneously, a generally accepted mainstream approach for measuring regional economic resilience does not exist, nor are its determinants and their relationship to agreed regional growth models agreed upon. All this ultimately results in misinterpretations and various alterations in the use of the concept of resilience.

Therefore, the key purpose of this article is to identify specific characteristics of the resilience concept in the context of socio-economic processes in regional development. The article is based on systematic literature research (see in Annex), which examines research works in the field of resilience and partial components of the resilience concept. In this case, the systematic literature research included literature documentation and screening, data extraction and analysis, and the final stage of writing literature research. In connection with the underlying research 
question of understanding and introducing the dimensions of resilience and the key measures, resp. indicators in the perspective of socio-economic resilience of the territory, appropriate works were obtained by using databases and accessible information sources. The works were selected based on comparing the individual dimensions of the resilience indicators closest to the given topic.

\section{Methodology}

As mentioned above, this article is based on systematic literature research, which was compiled through four phases, presented by Snyder (2019). These phases are as follows: Research Design; Research Implementation; Analysis and Research Writing. The individual phases were selected so as to answer the basic questions that are key to these phases. The first question (in the first phase) is whether this research of the literature is needed in relation to the overall area of research and whether its creation will have the desired benefits. Among other things, it is necessary to clearly define research questions and motivations for the design of literary research. Furthermore, whether there is relevant literature and whether the creation of research itself builds on previous research. In addition, it is necessary to establish key exclusion criteria and an appropriate procedure for the design of literary research. In the second phase, it is required to establish a proper literature research process and to establish appropriate control mechanisms. In addition, it is crucial to answer the question of whether the process of inclusion and exclusion of literature is sufficiently transparent and whether we can be sure that it is appropriate in the final sample of literature and following the overall purpose of literary research. In the third phase, when we are already working with the data, it is necessary to ensure that the data included in the article are in line with the overall purpose of the research. It is also essential to take appropriate measures to ensure quality data collection. In the fourth phase, which represents the structuring and writing of literary research, it is necessary to ensure the coherence of the research article concerning the overall approach and research questions.

Furthermore, it is necessary to ensure that the literature research results are sufficiently described and to check whether the article can be published. It is also crucial to ensure that the literature research results are described appropriately and clearly. It is also important that the article synthesises the literature search results into a clear and valuable form, beneficial to the topic. Finally, it is appropriate to include accurate questions or guidelines for subsequent research.

In this article, the method of descriptive overview is used, the primary goal of which is to determine the extent to which the set of knowledge in a particular research topic reveals any interpretable formula or trend concerning already existing propositions, theories, methodologies, or findings. This method follows a systematic and transparent procedure, including search, screening, and classification of studies. De facto, each study is considered as a unit of analysis and the published literature 
research, as a whole, is providing a specific database (see in Annex) from which the aim is to identify any interpretable trends or draw overall conclusions about the benefits of existing conceptualisations, propositions, methods or findings (Paré and Kitsiou, 2016).

\section{Theory of resilience}

In the past, national economies have always been inclined to various types of shocks, such as economic downturns, industrial shocks, currency crisis, and natural or health crisis, which can destabilise regional economic growth and nature. Such a shock-disrupted economy can shift to a new growth trajectory by restoring economic ties within the region and other regions. The analysis of the concept of resilience is primarily led by the fundamental question that arises in the study of resilience in the regional context, i.e. why one region is more prone to economic shocks than another. Thanks to the specifics of resilience, this concept has come to the fore across scientific disciplines and has become an almost integral part of the political debate. Although, as already mentioned, the importance of resilience is currently growing, not least due to the recent and still ongoing period of the global pandemic crisis, nowadays, there is no generally agreed approach to how the concept is supposed to be operationalised and analysed. Likewise, a generally accepted theory of regional economic resilience does not exist. Also, the quantification of regional economic resilience is a challenging issue for measuring and evaluating territory at any stage. In general, resilience can be described as the state of a system (country, region, country, city). Its characteristic factors tend to make the system economically resilient and simultaneously capable of harmonious development and progress in any change in the external environment. The most traditional meaning of the term in the socio-scientific literature on resilience is the ability of the regional economy to maintain its current status (considered as an equilibrium) in the simultaneous occurrence of an exogenous shock. Regions do not significantly differ in resilience from other systems, they are just as prone to unpredicted shocks. Therefore, the regional economies resilience is a good issue for academic research, not merely in itself but also due to its potential importance for information in policymaking. A profound study including various research aspects from environmental, economic, institutional, social, and political studies can provide a conceptual definition and a dependable and applicable complex analysis of regional economic resilience (Staníčková, 2017a; Staníčková, 2017b).

In understanding the theory of resilience, it is essential to realise that local, regional economies do not exist independently and are not isolated. We must thus resist the temptation to simplify resilience only to the local isolated level. The resilience of the domestic regional eco-economy will, in many cases, be shaped by conditions affecting the region from the outside, such as the strategies and decisions of policy makers, as well as government measures or corporate behaviour. On the 
other hand, there is a growing belief that the primary responsibility for local economies lies with the local people themselves and not with official governments (Martin and Sunley, 2020).

\section{Regional geography and resilience}

Thanks to scientific progress, access to a global understanding of the economic sphere has been acquired rapidly. As a result, scientists are considering the issue of economic resilience on a worldwide scale. Each school of economics assigned its methodology and context to analyse resilience, which matched the historical background of the evolution process. During the development of economic theory, the academic society was unable to answer a sub-question that would determine what indicators could lead to the well-being of society. New concepts were created with each new economic crisis that hoped to find a strong groundwork for sustainable growth and other tools to regulate the economic area until the next crisis. It is known that world economies are constantly inclined towards significant disruptions and shocks, such as recessions, major political changes, currency crises, mortgage crises, technological revolutions, unexpected health crises, which have disrupted and destabilised the path and structure of economic growth. These destabilising phenomena affected the economies regionally in the sense of state units and their sub-regions, urban and local economies, and communities, which caused specific effects and consequences.

Regarding their impact or content, the original shocks are sometimes spatially neutral at the national or global level. It is known that it is not uncommon for local and site-specific disorders to occur. It could be suggested that the resilience concept is relevant for analysing how regions respond to shock and recover from disruptions and hence understand the role that these disruptions can play in determining the territorial dynamics of economic progress and development across the crisis period (Martin and Sunley, 2015). Resilience represents preparedness for long-term threats and the ability of the system to return to a functional point despite changes and difficulties. The presence of resilience in the region implies that achieving economic wealth is more likely in regions that are diversified. Economic development can be unwholesome if economic shift disrupts the society base or boosts vulnerability to macroeconomic fluctuations from a regional development viewpoint. Therefore, growth programmes and recovery plans must be created to ensure that the fundamental values of the community are maintained while providing new economic opportunities. A focus on resilience in the area of economic development planning can maintain economic and social integrity. It creates sustainable development that is resilient to social deprivation and isolated from macroeconomic instabilities. Briguglio et al. (2009) claim that policies conducive to better macroeconomic stability and effectiveness, efficiency and effectiveness of the microeconomic market, good governance and social security are fundamental to resilience. The 
concept of regional economic resilience has become part of policymaking due to the growing interest from economic policymakers and international institutions. Resilience emerges as an essential term, whose time has arrived in political discussions across regions that lead to a new path to build regional economic resilience. The contemporary discourse has found immediate acceptance in various political authorities on a different scale, from the European Union, resp. the European Commission or the Organization for Economic Co-operation and Development, to the macroeconomic level, i.e., national authorities, as government, regional and local authorities, and municipal bodies. Local and regional resilience indices, similar to competitiveness indices, have been compiled to compare one locality with another, thus supporting policy efforts to build stronger resilience.

In order to have literature research implemented to the concept of regional resilience, the region can first be classified as a research object in the context of regional resilience. As Palekienea et al. (2015) mentioned, the region is most often seen as a territorial unit, part of the country or part of the world, characterised by unique environmental, demographic, social and economic society or environment, which differs from other (neighbouring) regions. From an economic point of view, the region is conceived as a socio-economic unit, which is characterised by the production structure of all formats of ownership, population, employment concentration and government institutions. A region is essentially a place of interaction at the social, political, cultural, and economic level (Agnew, 2001). Following the methodology of the European Union, different criteria can be employed to differentiate countries into lower territorial units, for example, regions divided according to two criteria (Eurostat, 2011):

- normative regions are a manifestation of political will; their "borders" are set based on the tasks assigned to the territorial community, the number of inhabitants needed for the efficient and economic performance of these tasks or cultural, historical and other factors;

- functional areas are characterised consistent with analytical requests; group zones based on geographic conditions (e.g., altitude or soil type) or the usage of socio-economic conditions (e.g. homogeneity, complementarity, or divergence of economies).

\section{Development of the resilience approach}

As it has already been mentioned, economic shocks occur regularly in economies, although their effects vary from one region to another, as do their adjustment and recovery. Following the issue of resilience, a fundamental question arises: why are some regional economies facing the adverse effects of shocks able to recover in a relatively short period, while others are not? The concept of economic resilience, which is often used, is rarely well defined. It is required to establish a precise definition, conceptualisation, and comprehension of economic resilience if 
we want to apply this idea meaningfully in regional policymaking. The first historical definition of resilience can be found in the Encyclopedia Britannica of 1824 resilience is defined as the ability of a tense body to regain its size and shape after deformation due to compressive stress or as the ability to recover or quickly adapt to disaster or change. Resilience has its root in the Latin word resilio/resilire, which means to jump back (Klein et al., 2003). The term resilience is then generally defined as the ability to return to its original status. It should be noted that a generally accepted definition of regional economic resilience does not exist, and different authors use different definitions (Staníčková, 2017b). For more information, see tables containing systematic literature research of this concept in the Annex.

Staníčková (2017b) states that most research studies understand resilience as the ability of any system to recover from an exogenous shock or the ability to absorb against attenuation (Rose and Krausmann, 2013; Briguglio et al., 2009; Brock et al., 2002). It follows that resilience includes the ability to cope with external factors and reduce vulnerability. One of the main tasks of resilience is to minimise losses and, as a result, ensure economic recovery in the shortest possible time. In terms of engagement and change management in general, resilience can be considered an attribute that is constantly present or lacking. On the other hand, adaptation in terms of coping with a particular shock is more episodic. There is a fundamental difference between resilience as a vital capacity and adaptation as a natural process, as adaptation can be observed from the changes made, and resilience cannot, as it can only be derived from fundamental adaptation processes and subsequent analysis of the underlying factors necessary for satisfactory adaptation. The term flexibility is most often used to refer to strength and flexibility. Two separate, not necessarily unrelated, concepts are distinguished. The first concept is based on the equilibrium analysis and resilience is understood as the ability to return to an existing state in a single equilibrium system. The second concept defines resilience as the complex adaptive system and concerns the system's power to adapt and change in response to shock (Weir et al., 2012). Flexibility includes adapting to normal or expected levels of stress and adapting to sudden shocks and extreme demands. In regional economic analysis, the most natural conceptual significance of resilience is the ability of the regional economy to maintain or return to an already existing state (considered to be equilibrium) in the presence of some kind of exogenous shock.

The extent to which a regional or national economy can return to its previous level or rate of growth in production, employment or population after an external shock is at the heart of the idea of resilience in Feyrer et al. (2007) or Rose and Liao (2005). As stated by Melecký and Staníčková (2015), Melecký (2015) or Melecký, and Poledníková (2012). A related notion of resilience is the extent to which the regional economy avoids disturbing its previous equilibrium state by an exogenous shock. Ideally, this could involve avoiding shock or resisting shock with little or no adverse effects, altogether. If the shock is completely avoided, it could be an economy independent of only one of the sectors concerned, it is likely to cope better 
with negative demand shock. A sufficiently diversified economy can then face shocks that will have a minimal macroeconomic effect on it. The resilience would then be a study of the rise, stability and disintegration of the institutions that are the basis of long-term regional economic growth. The economy would be resilient to the extent that its social structure would be stable or to the extent that it would move quickly from one system to another (Simmie and Martin, 2010). Based on Martin (2012), regional resilience is a multidimensional property involving four interrelated dimensions describing shock response: resistance, recovery, redirection, and recovery.

Within the framework of regional policymaking, a key aspect is to reveal what it is that determines the resilience of the regional economy, or thanks to which the regional economy is more or less resilient. Research describing patterns and determinants of impact resilience and/or economic resilience is sparse. Based on the scientific literature, there are specific factors that affect the region's ability to resist. Each factor is different in each area and changes over time. Regional literature points to several regions that can shock resistance or resilient (Staníčková, 2017b). According to Christopherson et al. (2010), the success of regions can be evaluated in no small extent by past and current economic growth, while the assessment is also adapted to change, convergence, and sustainability. Suppose we understand the region as a political and economic system, human activity, and social relations. In that case, it can be examined as a continuous process of transition through time and territory. This highlighted the importance of valuing the region's strengths and weaknesses in building regional development strategies, including identifying its assets and strengthening socio-spatial relationships between the social actors of capital, labour, the state and politics (Palekienea et al., 2015). The authors dealing with regional economic resilience noted that the location of the region as well as the climate are relevant to the development of the region, as was the case with Feyrer $e t$ al. (2007) who found that regions with warm and sunny climates and near metropolitan areas had higher population growth after the shocks of the 1970s and 1980s, when they were faced with job losses in the automotive and steel industries. Kolko and Neumark (2010) state that regions are expected to be more resilient to shocks with a negative impact on employment if smaller locally-owned chains are concentrated in the region.

Furthermore, there is evidence that regions with rapidly growing technologies and knowledge-based work are more resilient in terms of average earnings per worker. Simultaneously, regions attracting highly skilled workers have a more significant increase in average revenues per worker (Chapple and Lester, 2010). The broader literature on regional resilience, particularly the literature on resilience to natural disasters, also contains findings appropriate to regional economic resilience. In the literature, it is common to find that access to economic resources supports the resilience of regions or communities to natural disasters (Norris et al., 2008; Paton and Johnston, 2001), leading to an understanding of those regions with higher 
average incomes or wages which may recover more quickly from economic shocks. Resilient thinking is thus an alternative approach.

\section{Factors influencing resilience}

Under the pressure of increasing globalisation, rise of new technologies and growing roles of knowledge and learning processes, regions have undergone significant changes in recent decades. These new tendencies resulted in changes in production structures and work processes and changes in the built environment, lifestyles, and patterns of consumption, and such changes have eroded their resilience (Hudson, 2009). There are two types of factors shaping regional resilience, creative and adaptive ability. We understand the economic structure, innovation system, skills base, and level of competitiveness in the previous shock by intellectual skills.

In contrast, adaptive skills include combinations of actions and decisions necessary to accelerate regional recovery (Palekienea et al., 2015). According to Rose (2004), combining such capabilities and their interaction in a region can ensure that the region is resilient to shock. Currently, regions worldwide face pressures to reassess the impact of competitiveness and integration policies on the globalised economy and socio-spatial structures shaped by globalisation and competition (Eraydin and Tasan-Kok, 2013). Due to local differences, the effects of existing competitiveness assets can be quickly undermined. From an economic point of view, regions may become vulnerable due to reliance on global conditions and the dominance of deregulation measures. In such cases, the system may fail, leading to substantial reduction or total loss of performance. Subsequently, resources must be expended to restore system performance to normal levels.

Similarly, system performance can be specified as a path via multidimensional space measuring two dimensions of performance, i.e. efficiency and effectiveness. This understanding of system performance leads to a broader resilience concept and to the question: what are the main characteristics of regional economic resilience? According to Martin (2012), the critical factors of regional resilience include the dynamic growth of the region, the structure of the economy, export orientation and specialisation of the region, human capital, innovation rate, business and corporate culture, region location and institutional arrangement in the region. According to Foster (2006), the key factors in regional resilience include the economic capacity, the region's social-democratic capacity, and the capacity of the regional community. Koutský et al. (2012) deal with determinants of regional economic resilience and define the following factors: leading macroeconomic indicators, labour market indicators and others. According to the three sets of regional economic resilience factors above, Melecký and Staníčková (2015) or Staníčková and Melecký (2018) defined a set of regional economic resilience indicators (also important in terms of competitiveness). This understanding of resilience was used for the purposes of constructing a composite weighted regional resilience index - based on five 
extracted dominant factors (including indicators) of regional resilience: links to communities, human capital and socio-demographic structure, the labour market, economic performance, innovation, science and research (see Table 1 and Table 2).

These factors, which affect the resilience, are then the starting point for defining the areas for measuring resilience. Literature searches for the period 2006 to 2020 (see Table 1, Table 2 and Table 3) show that most authors still approach resilience comprehensively, in the sense that they admit that the region's resilience affects the level of GDP of the economy and the whole socio-economic background of the region. According to Melecký and Staníčková (2015), many authors also add environmental and natural aspects to the already mentioned five dominant factors (Giacometti and Teräs, 2019; Graziano, 2013; Miller et al., 2016; Psycharis, 2014; Renschler et al., 2010; Slach, 2013). The business or maybe microeconomic dimension, the specialisation of a given region, or the level of investment also appear to be in other publications, one of the critical areas to be addressed in the case of resilience (Pavlík, 2016; Asian Development Bank, 2016; Salvati, 2016). These dimensions or, better say, factors that affect the territory's resilience contain indicators approximating which factors affect resilience. The main indicators include the level of GDP as a leading representative of macroeconomic stability. Other indicators of macroeconomic stability include, e.g., the level of household savings, gross domestic fixed investment, consumption, growth, trade, inflation, the ratio of fiscal deficit to GDP, the sum of unemployment and inflation, external debt to GDP ratio, employment stability (Ekosgen, 2009; Briguglio, 2009; Economic Commission for Latin America and the Caribbean, 2011; Dabson et al., 2012; Anuradha and Ragab, 2012; Modica, 2018; Staníčková, 2017a; Ženka and Slach, 2018). These factors of economic performance of the region are affected (and closely connected with) by human capital industrial diversity, social capital, infrastructure, labour market, export orientation, quality of institutions as well as R\&D development and expenses (Caldera-Sanchez, 2016; Chacon-Hurtado et al., 2020; Ekosgen, EDAW/AECOM, 2009; Fratesi and Perucca, 2018; Hlaváček, 2013; Mancini et al., 2012; Kahsai et al., 2015; Rakotomanjaka, 2014; Randa, 2013; Svoboda, 2013a; Svoboda, 2013b). Socio-demographic factors such as population density, the proportion of the young population, proportion of the older people, net migration rate, social capital, population level, people at risk of poverty or social exclusion, people living in households with very low work intensity, people at risk of poverty after social transfers, severely handicapped people, healthcare expenditures, medical staff, medical facilities, road deaths, life expectancy with health, infant mortality, cancer mortality, heart disease mortality, suicide (FAO, 2016; Gianmoena, 2018; Staníčková, 2017a). Miller (2016) measures economic resilience via an index composed of economic diversity, entrepreneurship and dynamic economy, and social resilience as a sum of indicators, reflecting education, social capital, health, and attachment to the place, forming the social resilience index. Social resilience means the sum of the following indicators, which together include the social 
resilience index: attachment to the place, highly educated population, civic engagement, social capital, healthy population.

\section{The European Union and the concept of resilience}

As stated in Romanova (2020), the European Union has been working with the concept of resilience since the time of the European Economic Community. In the 1970s, the concept of resilience emerged in connection with the problems associated with internal development and overcoming these problems, especially in connection with ensuring economic growth and resilient development. Later, in the 1990s, this concept was rooted in the security sphere, whose the priority was to protect the population and ensure security. At the turn of the century, this concept became an integral part of the Union's relations with developing countries, whose priority was to use the concept of resilience to demonstrate the EU's external action and, above all, to stimulate the resilience of these partners. Simultaneously, on EU soil, the concept of resilience is becoming part of the agenda to promote the Union's democratic values, respect for human rights and the rule of law. Thus, the European Union has based its concept of resilience on solving internal problems and help to solve external global problems. Due to this approach, the Union has become a model to be followed in building resilience. From the history of the application of the concept of resilience at the European Union level, it can be said that the Union focused mainly on security and protection of democratic values, which are part of the EU's global strategy, where the Union focused on protection against cyber threats, terrorism, and security of energy supply (European External Action Service, 2016). However, with the advent of the pandemic, a reversal in the concept of resilience occurs. Before the pandemic, the concept of resilience focused on external relations with third countries, emphasising resilience to external security threats. The pandemic has changed the European Union's approach towards internal transformation and focuses on addressing internal challenges. In the EU, however, the external dimension of resilience has not disappeared. Strengthening the resilience of foreign partners is still part of the EU's neighbourhood policy. As Meszaros and Toca (2020) point out, building resilience in the neighbourhood has become one of the EU's top foreign priorities. These policies have one main goal: to build resilient states and society in the vicinity and create a team unrestricted economic growth and functioning within the Community.

Although the term resilience appeared in the context of environmental resilience in the past, the area of economic resilience was not as dominant as it is nowadays. Environmental resilience is currently being looked at mainly from the perspective of ensuring sustainability for future generations. As Bănică and Muntele state, a resilient and sustainable city (or in this case region) represents economic growth or environmental renewal and the principles of equal opportunities for the 
entire population, ensuring a decent environment and a healthy and safe environment.

In regional resilience, the emphasis on the economic aspects of resilience or the development of innovations persisted for a long time. With the growing interest in climate change, this concept comes to the forefront of national policymaking, but not as a necessary part of regional resilience policymaking. However, the turning point is taking place in the European Union, which has built environmental resilience, including green transformation, among the main dimensions of resilience, including social and economic dimension, geopolitical dimension, green dimension, digital dimension. In this respect, the EU is an innovator integrating the goal of building Member States' more resilient economies into all policies and does not forget them in the area of cohesion policy (European Commission, 2020a). Another novelty "brought" by the Union is the digital dimension, which seems to respond to the current pandemic situation; the emphasis is on the importance of digital protection for citizens and states and on the need for digital development and education among citizens. The digital aspect of resilience is also reflected in the new Digital Economy and Society Index (DESI) resilience measurement methodology, which includes a category of key DESI indicators for economic recovery, for which the following four indicators are key: very high-capacity networks (VHCNS) and $5 \mathrm{G}$, digital skills, advanced digital technologies for businesses, digital public services. The DESI concept is built on five dimensions: connectivity, human capital, use of the internet, integration of digital technology, digital public services (European Commission, 2020b).

Among other things, the European Union is pushing for a health union to build resilience, especially in response to a pandemic situation, which would ensure the resilience of states in the hitherto relatively neglected health policy under shared/supportive public health policy (Eur-lex, 2020). Building a health union has previously been seen as something that needs to be achieved and, at the same time, as something very controversial, but this attitude has changed in the face of an unexpected shock in the form of a health crisis. As such, it is appropriate for future research to determine the research question of whether it is unlikely that some hitherto controversial areas of economic resilience are controversial until the arrival of a completely new shock that will change this attitude. In addition to these concepts, the Union is introducing the first recovery instrument and other financial instruments supporting the main objective for the next four years, namely, to ensure a complete recovery from the COVID-19 pandemic. The major financial packages include the Recovery and Resilience Facility (RRF), whose structure and objectives include key areas of the resilience dimensions already mentioned, such as helping the EU achieve its 2050 climate neutrality target, set it on a path of digital transition, creating jobs and spurring growth in the process; minimum of $37 \%$ of expenditure on investments and reforms contained in each national recovery and resilience plan 
should support climate objectives (European Commission, 2020; European Commission, 2020c).

With the establishment of the RRF, the Union moves the concept of resilience to the national level. Member States that will benefit from this instrument must submit National Recovery Plans which must correspond to the already built resilience concept. At the same time, the EU strategic documents still retain the older concept of resilience, i.e., towards strengthening external resilience vis-à-vis third countries, building the resilience of developing countries and, finally, strengthening resilience in security with emphasis on cyber defence and combating disinformation, a phenomenon that has been increasing in recent years (Romanova, 2020).

According to Le Maire (2020), the main goal is to build the foundations of economic sovereignty by investing in green value chains, such as the recycling industries and the circular economy, contributing to reducing energy dependence. Romanova (2020) builds on this context and emphasises that energy sovereignty can currently be seen as a cornerstone of European policy. Given the pandemic crisis, green transformation, and precarious relations with Russia, energy diversification and development of strategic energy accumulation are key to strengthening independence and resilience.

It follows from the above that the European Union focuses on the recovery process from a pandemic by building something new, not by going back. Overall, the EU objective is to ensure a stronger and more resilient digital and green transformation and economic recovery towards the future, which is represented, among other things, by the $4^{\text {th }}$ Industrial Revolution (also known as 4IR) ${ }^{1}$.

\section{Response of the European Union to the COVID-19 - a focus on resilience}

In December 2019, the Covid-19 pandemic hit China and the COVID-19 outbreak in China itself can be divided into three phases. From December to 20 January, 2020, there was a so-called epidemic awakening stage in China, when a pandemic broke out and gradually spread throughout the world. Then, between 21 January, 2020 and 21 February, 2020, the quarantined economy was marked by the fact that Wuhan became the epicentre of the spread of the pandemic. From 21 February, 2020, there was a "back to work" stage in China while the virus was spread globally, around the world (Gong et al., 2020). From this, it would be suggested that, since February 2020, China has been in a period of economic recovery; however, Coronavirus has had strong impacts in other parts of the world where authorities tried to implement appropriate measures to curb its spread; nevertheless, it should be borne in mind that the pandemic came in the so-called waves, which are spreading

\footnotetext{
${ }^{1}$ Since the transition from an agrarian society to an industrial society, the world economy has undergone three industrial revolutions. We are currently on the threshold of the $4^{\text {th }}$ Industrial Revolution, called 4.0 or 4IR.
} 
around the world with a certain delay precisely as a consequence of the relevant measures implemented by governments. At present, it is still challenging to estimate at what stage of the economic cycle individual economies, including China, are at a time as new mutations of the virus are constantly emerging around the world.

The 2020 pandemic has been a shock for all countries, and no economy has been untouched by losses suffered both in terms of human lives and livelihoods. At the same time, the European Union faces a pandemic and a planetary emergency as does the whole world. The systemic nature of the transformation has significant consequences for public policy, especially for its capacity and ability of governments to address each new crisis not in the way it arises but conceptually. Given the complexity of its multi-level governance and applicability of the principle of subsidiarity which involves all levels of government, this aspect is important for the European Union. In this context, the issue of COVID-19 has opened up other (hidden) challenges in the EU, i.e., institutional issues and the depth of the integration process. As Barbier-Gauchard et al. (2021) stated, the European institutional architecture can be viewed as being halfway between an association of sovereign states (like the United Nations) and a politically integrated federation (like the United States). In this original construction, competences on several matters are shared at the European, national and local levels in more complex ways than in fully integrated federations. To improve the EU's resilience to violent external shocks, Barbier-Gauchard et al. (2021) determined the extent to which these competences should be transferred to the federal level. In this respect, Barbier-Gauchard et al. (2021) consider whether a federal leap is necessary in several areas, namely (i) monetary and fiscal policy (rules), (ii) labour markets policy and social models, migratory flows and skill shortages, and cooperation policy and (iii) renewed industrial policy and exchange rates. Despite a highly uncertain context, BarbierGauchard et al. (2021) outlined some perspectives for the future of the EU.

The European Commission is aware of the need for forward-looking options rather than quick fixes to great emergencies. Going back to the pre-COVID-19 models of growth is not a solution - the significant emphasis should be placed on valuing "sufficiency" and "essential job" creation. The COVID-19 crisis has exposed several vulnerabilities in the EU, as a whole, as well as in the individual Member States. An analysis of the impacts of the crisis reveals severe disruptions across the EU's economy and society. The regional and local impact of the COVID-19 crisis is highly heterogeneous, with a strong territorial dimension that has significant consequences for crisis management and policy responses. On a sub-national scale, governments are responsible for crucial issues of containment measures, healthcare, social services, economic development, and public investment, putting them in the front line of crisis management (OECD, 2020b). However, previous studies dealing with a public policy against COVID-19 mainly focused on analysing and comparing policy measures on a national scale (e.g., OECD, 2020b, European Centre for Disease Prevention and Control, 2020; Eurofund, 2020), whilst those taken on the 
regional and the local scales were rather overlooked. A few exceptions include reports from OECD and the United Nations (UN), which have significantly advanced the knowledge on first policy answers on the regional and local scales. These reports paid special attention to measures taken by urban areas, considering that cities were and still are in the front lines of the COVID-19 crisis (OECD on City Policy responses (OECD, 2020a); UNESCO on learning from cities' reactions to COVID19 (UNESCO, 2020); UNITED NATIONS on a Policy Brief on COVID-19 in an Urban World (UN, 2020)), whilst regional policies have mostly been ignored. Overall, various organisations have put great emphasis on the collection of city responses to the ongoing crisis. However, systematic comparative approaches that facilitate cross-regional and cross-city policy learning have not been conducted yet. Consequently, there is still a need for an overview of the nature of local and regional policy answers across the EU and a need for a proper understanding of territorial commonalities and differences in tackling the consequences of the pandemic. In general, examining any impacts at the EU regional or local levels (i.e., not national) is a significant challenge.

But what is the strategy at the highest - supranational level, i.e., the EU level? Ensuring effective recovery spending is a high-stakes challenge for the European Union, with the potential for derailment because of fuzzy objectives and overloaded procedures. The EU should work with the Member States to identify limited policies that will maximise the impact of EU investment while accounting for spillovers. The European Commission President's political guidelines and principles set a long-term strategic direction to transition towards a green, digital and fair EU. The recovery plan for the EU shows the way in the future: the Next Generation EU strategy aims to build a more resilient, sustainable, and fair EU via large-scale financial support for investment and reforms. The report's strategic foresight will play an essential role in providing future-proof EU policymaking by ensuring that short-term initiatives are grounded in longer-term goals (European Commission, 2020a). The central theme of the current version of the report, resp. the first version of the report, strategic foresight (from 2020), is resilience becoming a new compass for EU policies tackling the impacts of the COVID-19 crisis. Resilience is the ability to withstand and cope with challenges and undergo transitions in a sustainable, fair, and democratic manner. According to the understanding of the European Commission (2020a), resilience is necessary in all policy areas to undergo green and digital changes while maintaining the EU's core purpose and integrity in a dynamic and turbulent environment. A more resilient EU will recover faster and will emerge stronger from the current and future crises. The EU's focus on resilience calls for close monitoring to move towards resilience dashboards in four resilience dimensions: the societal dimension, the economic dimension, the social dimension, ecological dimension, and the innovative dimension. 


\section{The $4^{\text {th }}$ Industrial Revolution and regional resilience}

The globalised world is currently under pressure from the Fourth Industrial Revolution, which forms the boundaries between the physical, digital, and biological worlds. Technological progress in artificial intelligence, robotics, automation, and other technologies, which significantly impact the future distribution of forces on the labour market as their region and their resilience, is coming to the fore. Such technological development has a significant impact on the current way of life. It leads policymakers to change their design, focusing on the fastest transition to a climate-neutral and circular economy. In this way, policies that fall into the desired state will become potentially more resilient to adverse shocks and significantly increase their competitiveness in the global market. We know from the past that the fourth industrial revolution will impact all areas of politics once revolutionstriggered transitions are fulfilled. The first industrial revolution began in the $18^{\text {th }}$ century with the advent of steam engines enabling mechanisation and was the driving force for the social changes that followed the growth of urbanisation. At the beginning of the $19^{\text {th }}$ century, scientific progress led to mass production. Thanks to scientific and technological progress, the third industrial revolution dating back to the 1970s enabled computers and digital technologies development. Thus, history shows that scientific and technical progress had a significant impact on every industrial revolution, which led to a massive shift in the professional structure, the extinction and emergence of new occupations which, on its turn, has a significant impact on the prosperity of regions and cities (OECD, 2018; OECD, 2019). As a result of the recent economic crisis and the Industrial Revolution 4.0, the world's regions have focused on monitoring the level of research, innovation, and entrepreneurship to ensure greater competitiveness of the region in the future world. This phenomenon of focusing on research and innovation is also reflected in defining the dimensions of resilience. Education, quality of human capital, education capacity, knowledge and innovation system factors innovation and research and development, innovation and research capacity have thus become among the partial dimensions that are key for building regional resilience (Salvati, 2016; Pavlík, 2016; Staníčková, 2017a, 2017b; Staníčková and Melecký, 2018; Gianmoena and Rios, 2018; Giacometti and Teräs, 2019).

In response to 4IR, the European Commission has incorporated a new concept called "smart specialisation" into the Europe 2020 Strategy for smart, sustainable, and inclusive growth. This new concept is aimed to support improvement in innovation and competitiveness in the region's existing sectors by highlighting existing knowledge and know-how and by using specialised research activities to enable them to compete internationally (Kogut-Jaworska, 2015). For a region to achieve these goals, smart specialisation requires understanding the region's strengths and weaknesses compared with other regions. Due to the differences between individual regions, the actual introduction of smart 
specialisation is different. To meet the strategy's goals of reducing unemployment and improving the quality of life, the presence of several success factors is essential, including:

- a broad definition of innovation combining technology and research-based innovation; using regional resources, infrastructure and competencies to develop the potential for competitive advantage over other regions;

- governance cooperation, combining top-down strategic leadership, prioritisation and monitoring based on analysis and facts, together with dynamic business processes based on broad stakeholder involvement;

- the ability to prevent the effects of blockages through diversification and cooperation between industries, clusters and industries;

- the ability to avoid fragmentation and the current ability to create sufficient relevant interregional and global links; the ability to promote dialogues between local, regional, national and transnational levels and communication.

An important factor for smart specialisation has been the assumption that the limited resources following the 2008-2009 economic crisis will force European regions to use resources more efficiently by setting research and innovation priorities. Although the concept has become very popular in the political sphere, there has been a problem in understanding "smart" in relation to the diversity of regions in the European Union and at the national level. For small regions, "smart" could mean diversification of industries while for more significant regions, the term could mean coordination between clusters, industries, fields, and specialisations (Lindqvist, 2013).

In Grochowski (2014), twenty types of smart specialisations were applied to the case of Poland. These types included: safe food; ICT; chemistry; lumber and furniture; bioeconomy; medicine and health; mechanical, electrical and metal engineering; business services; sea and water transport; energy production (including renewable energy sources); construction; mining industry; creative industries; offshore technology; textile industry and design; production of goods from synthetic materials; water management; the high quality of life; aviation and astronautics and the Easter Gate. It follows that there are two approaches to smart specialisation (focusing on specific industries or groups to form the basis for smart specialisation) and processing (focused on the links between different regional potentials - economic, institutional, and social).

\section{Conclusions}

How well do we actually know the issue of resilience? Based on literature research, it is evident that resilience is not simple and that resilience extends into various spheres of life. Resilience is a tendentious topic regarding the diversity of shocks, whether economic, environmental or health-related; each shock emphasises the system's fragility and forces us to respond to things that we cannot control firmly. 
It is necessary to consider that current strategies aimed at strengthening resilience correspond to a given type of shock at a given place and time. Therefore, these strategies will differ. Although resilience strategies will vary due to the diversity of shocks, any shock will have an economic impact. In this respect, it is essential to set up the basic research question that accompanies economic policy, and that is how to solve the problem of time delays in policy implementation. The implementation of measures to support the resilience of regions, whether countries or sub-territories, faces political and economic cycle mismatches. These time delays may result in the late implementation of a strategy focusing on one area of strengthening resilience at the expense of another and, in the meantime (before a political consensus and strategy implementation is reached), a shock affecting the "neglected" area of resilience may occur. It follows that it is essential that strategies aimed at developing and strengthening the resilience of the regions be as comprehensive as possible and do not omit the seemingly insignificant areas of human life and the related policies that address them. We could say that the resilience of regional economies was already a priority for the regions during the first industrial revolution, which fuelled changes in the distribution of power resources in the world. Since then, the importance of technology and specialisation of the region have become more important in developing the region's growth and competitiveness. As in the first case, the impact of the Fourth Industrial Revolution will affect the whole world society, not only in terms of technological development but especially in changes applied to human capital structures to ensure sustainable growth and development to the greatest extent possible. Therefore, regions must be prepared for these.

Otherwise, 4IR could be a shock for them. So how to make resilience for 4IR? Based on literature searches, it follows that support of innovation, research and development and human capital development, which must already be supported at the level of regional policymaking, are fundamental. The European Union has responded to these demands by incorporating the key concept of "smart specialisation" into its Europe 2020 strategy, making efficient use of public resources for regional specialisation to ensure the region's sustainability and competitiveness. This concept was introduced to overcome criticism of previous similar concepts such as clusters, innovation systems and open innovation platforms, which were mainly criticised for their fragmented or overlapping investments. This concept has gained significant political appeal (and resilience) since its introduction, so it might seem that it could be more effective than its predecessors. As with resilience, the region's size, resources, macroeconomic stability, etc., all play a role in the smart specialisation. Therefore, the setting of this concept cannot be unified in any way for the set of policies of individual regions.

Innovation and smart specialisation are key aspects for the resilience and future competitiveness of the region. However, it is necessary to be aware of the delay in creating policies that should support these two coveted features of the region. We are currently living at a breakneck pace, and we are under pressure from 
information and rapid technological progress. Assuming that the region's resilience to continuous competitiveness is to be maintained, it is necessary to effectively use public and private resources so as to develop scientific research and invoicing at the lowest regional level while supporting the above mentioned trends.

It is necessary to emphasise the ambiguity of the perception of the concept and the resulting number of authors and approaches to the theory and measurement method. Due to the pandemic crisis and the emphasis placed by the European Union, building resilience is becoming part of the reconstruction policy of many states in Europe, and it can be assumed that this concept will follow for many others. However, controversy arises in the area of what the state/region/city considers to be key in building resilience. There is an excellent diversity of states, regions, cities, not only in the European Union but also in any other state at the global level, so each region within a state welcomes resilience indicators which are different from others. The most significant case of controversy about economic indicators is industry. For many countries, the industry is a key aspect. And it is even more so for a region that benefits from it economically through the population that lives, works, studies, and builds a life for future generations there. There is a risk that while promoting environmental resilience will, on the one hand, improve the quality of life and health in the area, the effect that will be mostly, felt by the population will be the loss of jobs and the other associated effects on the economy. Although states try to save the situation through various packages to rebuild economies and build resilience in the face of pandemics, there is a threat that the effects of the transformation of economies towards resilience, suppressed by social consensus, will not be welcomed. This raises the question of whether a pandemic is an ideal situation for building resilience through recovery tools concerning the population's adaptability during a crisis, or whether it is a threat to economies and regions that may be irreversibly weakened?

Considering the COVID-19 crisis, the EU needs to boost its resilience and look forward, i.e., recover, but emerge stronger by intensifying transition-led political agenda. Now, national governments are struggling to absorb the shock generated by the pandemic but, in time, the international community will overcome the crisis and begin the recovery phase. In the longer term, an approach that reacts to the systemic origins and impacts of major shocks is needed if policies are to be effective.

The COVID-19 pandemic has shown just how important it is to have resilient systems in place to manage unexpected shocks. The systemic nature of risk with multi-sectoral impacts and its cascading effects, where one disaster can rapidly lead to another, demonstrate how complex and deadly disaster risks have become. In COVID-19, a biological hazard revealed the precarious systems upon which trade, food, energy, transportation, and social safety nets rely. To tackle the current and future emergencies, there is a critical need to apply a multi-hazard lens to increase resilience at all levels, to strengthen health systems and develop strategies that address an extensive range of hazards and socio-economic factors. 
For survival and future developments, the EU needs to learn from the current pandemic situation. One of the lessons that the EU draws from the pandemic is that it is vital for survival to anticipate further developments based on the principle of sustainability, i.e., to find the balance between the well-being of current and future generations. The direct investment should point to enhanced protection from the adverse impacts of social, economic, and environmental shocks; better preparation to face emerging large-scale risks and profound transformation to reconcile sustainability with resilience in the future should apply at all territorial levels. The uneven circulation of COVID-19 across the European regions raised immediate geographic questions regarding the pandemic's socio-economic, environmental, financial and demographic dimensions. The effects of the coronavirus crisis at the national level are known; it will take some time to understand the regional effects (given the delays in the reported data). Why were some areas hit harder than others? How could regional variations be explained? Is it possible to identify links between the spread of the disease and territorial characteristics likely to influence it? These are the questions for further research oriented on the regional impacts of the current crisis.

Acknowledgement: The article is supported by the SGS project (SP2021/50) of Faculty of Economics, VŠB-TUO.

\section{References}

Agnew, J. (2001), Regions in revolt, Progress in Human Geography, 25(1), pp. 103-110. https://doi.org/10.1191\%2F030913201673210318

Anuradha, S. and Ragab, A. (2012), Macroeconomic Vulnerability in Developing Countries: Approaches and Issues, Working Paper No. 94, Poverty Group, Bureau for Development Policy, United Nations Development Programme.

Asian Development Bank (2016), Asian Economic Integration Report 2016 Economic Outlook and Resilience, Manila, ADB.

Bănică, A. and Muntele, I. (2017), Urban transitions and resilience of Eastern European Union cities, Eastern Journal of European Studies, 8(2), pp. 45-69.

Barbier-Gauchard, A., Dai, M., Mainguy, C., Saadaoui, J., Sidiropoulos, M., Terraz, I. and Trabelsi, J. (2021), Towards a more resilient European Union after the COVID-19 crisis, Eurasian Economic Review, pp. 1-28. https://doi.org/10.1007/s40822-021$\underline{00167-4}$

Barbier-Gauchard, A., Dai, M., Mainguy, C., Saadaoui, J., Sidiropoulos, M., Terraz, I. and Trabelsi, J. (2021), Towards a more resilient European Union after the COVID-19 crisis, Eurasian Economic Review, pp. 1-28. https://doi.org/10.1007/s40822-021$\underline{00167-4}$ 
Briguglio, L., Cordina, G., Farrugia, N. and Vela, S. (2009), Economic Vulnerability and Resilience Concepts and Measurements, Oxford Development Studies, 37(3), pp. 229247. https://doi.org/10.1080/13600810903089893

Brock, W.A., Maler, K.G. and Perrings, C. (2002), Resilience and sustainability: the economic analysis of nonlinear systems, in: Gunderson, L.H. and Holling, C.S. (eds.), Panarchy: Understanding Transformations in Systems of Humans and Nature, Washington: Island Press, pp. 1-27.

Caldera-Sánchez, A., DeSerres, A., Gori, F., Hermansen, M. and Röhn, O. (2016), Strengthening Economic Resilience: Insights from the Post-1970 Record of Severe Recessions and Financial Crisis, OECD Economic Policy Papers, No. 20, OECD Publishing.

Chacon-Hurtado, D., Kumar, I., Gkritza, K., Fricker, J.D. and Beaulieu, L.J. (2020), The role of transportation accessibility in regional economic resilience, Journal of Transport Geography, 84, p. 102695. https://doi.org/10.1016/j.jtrangeo.2020.102695

Chapple, K. and Lester, T.W. (2010), The Resilient Regional Labour Market? The US Case, Cambridge Journal of Regions, Economy and Society, 3(1), pp. 85-104. https://doi.org/10.1093/cjres/rsp031

Christopherson, S., Michie, J. and Tyler, P. (2010), Regional Resilience: theoretical and empirical perspectives, Cambridge Journal of Regions, Economy and Society, 3(1), pp. 3-10. https://doi.org/10.1093/cjres/rsq004

Cutter, S.L., Barnes, L., Berry, M., Burton, C., Evans, E., Tate, T. and Webb, J. (2008), A place-based model for understanding community resilience to natural disasters, Global Environmental Change, 18(4), pp. 598-606. https://doi.org/10.1016/j.gloenvcha.2008.07.013

Dabson, B., Heflin, C.K. and Miller, K. (2012), Regional Resilience: Research and Policy Brief (retrieved from https://www.nado.org/wp-content/uploads/2012/04/RUPRIRegional-Resilience-Research-Policy-Brief.pdf).

Economic Commission for Latin America and the Caribbean (2011), Study on the vulnerability and resilience of Caribbean Small Island Developing States (SIDS), ECLAC (retrieved from https://repositorio.cepal.org/handle/11362/38568).

Ekosgen (2009), Index of Economic Resilience Sheffield City Region Report (retrieved from https://docplayer.net/40145626-Index-of-economic-resilience-sheffield-city-regionreport-reference.html).

Ekosgen (2009), Scottish Index of Economic Resilience. Glasgow: EkosGen, 2009 (retrieved from http://edas.org.uk/resources/ekosgenscottishresilience.pdf).

Eraydin, A. and Tasan-Kok, T. (2013), Resilience Thinking in Urban Planning, Amsterdam, Springer Netherlands.

Eur-Lex (2020), Communication from the Commission to the European Parliament, the Council, the European Economic and Social Committee and the Committee of the Regions. Building a European Health Union: Reinforcing the EU's resilience for cross-border health threats. $\operatorname{COM(2020)~} 724$ final, 11 November, Brussels (retrieved from https://eur-lex.europa.eu/legal-content/EN/TXT/?uri=CELEX:52020DC0724). 
Eurofund (2020), COVID-19: Policy Responses across Europe (retrieved from https://www.eurofound.europa.eu/publications/report/2020/covid-19-policyresponses-across-europe).

European Centre for Disease Prevention and Control (2020), Data on Country Response Measures to COVID-19 (retrieved from https://www.ecdc.europa.eu/en/publicationsdata/download-data-response-measures-covid-19).

European Commission (2020), EU's next Long-Term Budget \& NextGenerationEU: Key Facts and Figures. European Union (retrieved from https://ec.europa.eu/info/ sites/info/files/about_the_european_commission/eu_budget/mff_factsheet_agreemen t_en_web_20.11.pdf).

European Commission (2020a), 2020 Strategic Foresight Report. Charting the Course Towards a more Resilient Europe (retrieved from https://ec.europa.eu/info/sites/info/ files/strategic_foresight_report_2020_1.pdf).

European Commission (2020b), Shaping Europe's digital future.Digital Economy and Society Index (DESI) 2020 (retrieved from https://digital-strategy.ec.europa.eu/en/ library/digital-economy-and-society-index-desi-2020).

European Commission (2020c), Joint Conclusions of the European Parliament, the Council of the European Union and the European Commission on Policy. Objectives and Priorities for 2020-2024 (retrieved from https://ec.europa.eu/info/sites/info/ files/joint-conclusions-policy-objectives-2019-2024_en.pdf).

European External Action Service (2016), A Global Strategy for the European Union's Foreign and Security Policy (retrieved from https://eeas.europa.eu/topics/eu-globalstrategy/17304/global-strategy-european-unions-foreign-and-security-policy_en).

Eurostat (2011), Regions in the European Union. Nomenclature of territorial units for statistics, Luxembourg, Publications Office of the European Union.

FAO (2016), RIMA-II Resilience Index Measurement and Analysis - II, Food and Agriculture Organization of the United Nations, Rome.

Feyrer, J., Sacerdote, B., Stern, A.D., Saiz, A. and Strange, W.C. (2007), Did the rustbelt become shiny? A study of cities and counties that lost steel and auto jobs in the 1980s, Wharton Papers on Urban Affairs, pp. 41-102.

Foster, K.A. (2006), A case study approach to understanding regional resilience, California, Institute of urban regional development, University of California (retrieved from https://www.econstor.eu/obitstream/10419/59413/1/592535347.pdf).

Fratesi, U. and Perucca, G. (2018), Territorial capital and the resilience of European regions, Annals of Regional Science, 60(2), pp. 241-264. https://doi.org/10.1007/s00168-017$\underline{0828-3}$

Giacometti, A. and Teräs, J. (2019), Regional Economic and Social Resilience: An Exploratory In-Depth Study in the Nordic Countries NORDREGIO REPORT 2019, 2 , Stockholm: Nordregio 2019. https://doi.org/10.30689/R2019:2.1403-2503

Gianmoena, G. and Rios, V. (2018), The Determinants of Resilience in European Regions During the Great Recession: a Bayesian Model Averaging Approach. Discussion Papers 2018/235, Dipartimento di Economia e Management (DEM), University of 
Pisa, Pisa, Italy (retrieved from https://www.ec.unipi.it/documents/Ricerca/ papers/2018-235.pdf).

Gong, H., Hassink, R., Tan, J. and Huang, D. (2020), Regional Resilience in Times of a Pandemic Crisis: The Case of COVID-19 in China, Journal of Economy and Human Geography, 111(3), pp. 497-512. https://doi.org/10.1111/tesg.12447

Graziano, P. (2013), Vulnerability And Resilience Of The Economic, Social And Environmental Dimensions Of Italian Provinces, Regional Studies Association European Conference 2013 (retrieved from https://www.regionalstudies.org/wpcontent/uploads/2018/07/Graziano2013.pdf).

Grochowski, M. (2014), Development Potentials and Smart Specialisations, Warsaw: Ministry of Infrastructure and Development, National Territorial Observatory, pp. 167-172.

Hill, E.W, Wial, H. and Wolman, H. (2008), Exploring Regional Economic Resilience, Working Paper 2008-04, Berkeley: Institute Urban and Regional Development.

Hlaváček, P. (2013), Economic and Innovation Adaptability of Regions in the Czech Republic, Technical University of Liberec, $11^{\text {th }}$ International Conference Liberec Economic Forum, Liberec, Czech Republic, pp. 194-203

Hudson, R. (2009), Resilient regions in an uncertain world: Wishful thinking or practical reality?, Cambridge Journal of Regions, Economy and Society, 3(1), pp. 11-25. https://doi.org/10.1093/cjres/rsp026

Kahsai, M., Yu, J., Middleton, M., Schaeffer, P. and Jackson, R. (2015), A Framework for Measuring County Economic Resilience: An Application to West Virginia, Region Research Institute Working Paper Series (West Virginia University), Working Paper No. 2015-03, West Virginia University, West Virginia.

Klein, R.J.T., Nicholls, R.J. and Thomalla, F. (2003), Resilience to natural hazards: How useful is this concept?, Environmental Hazards, 5(1-2), pp. 35-45. https://doi.org/10.1016/j.hazards.2004.02.001

Kogut-Jaworska, M. (2015), Identification of Smart Specialisations in Polish Regions in the Context of the EU's New Financial Perspective 2014-2020, Oeconomia Copernicana, 6(2), pp. 23-36. https://doi.org/10.12775/OeC.2015.010

Kolko, J. and Neumark, D. (2010), Does Local Business Ownership Insulate Cities from Economic Shocks?, Journal of Urban Economics, 67(1), pp. 103-115. https://doi.org/10.1016/j.jue.2009.08.006

Koutský, J., Rumpel, P. and Slach, O. (2012), Profilace měkkých faktorů regionálního rozvoje jako nástroj posilování regionální odolnosti a adaptability, Certifikovaná metodika Ministerstva pro místní rozvoj, Ústí nad Labem: Univerzita J.E. Purkyně v Ústí nad Labem.

Le Maire, B. (2020), Strengthening the EU's resilience and strategic autonomy (retrieved from https://www.europeanfiles.eu/industry/strengthening-the-eus-resilience-andstrategic-autonomy). 
Lindqvist, M., Smed, Olsen, L., and Haukur Claessen, L.P.O. (2013), Implementing the Concept of Smart Specialisation in the Nordic Countries. An Exploratory Desk Study, Working paper No. 1, NORDREGIO, Layout: Allduplo, Stockholm, Sweden.

Mancini, A., Salvati L., Sateriano, A., Mancino, G. and Ferrara A. (2012), Conceptualising and Measuring the Economic issues in the Evaluation of Socio-ecological Resilience: A Commentary, International Jurnal of Latest Trends in Finance and Economic Sciences, 2(3), pp. 190-196.

Martin, R. (2012), Regional economic resilience, hysteresis and recessionary shocks, Journal of Economic Geography, 12(1), pp. 1-32. https://doi.org/10.1093/jeg/lbr019

Martin, R. and Sunley, P. (2015), On the notion of regional economic resilience: conceptualisation and explanation, Journal of Economic Geography, 15(1), pp. 1-42. https://doi.org/10.1093/jeg/lbu015

Martin, R., Sunley, P., Gardiner, B. and Tyler, P. (2016), How Regions React to Recessions: Resilience and The Role of Economic Structure, Regional Studies, 50(4), pp. 561585. https://doi.org/10.1080/00343404.2015.1136410

Matin, R. and Sunley, P. (2020), Regional economic resilience: evolution and evaluation, in Bristow, G. and Healy, A. (eds.), Handbook on Regional Economic Resilience, Cardiff: Cardiff University, pp. 10-35. https://doi.org/10.4337/9781785360862.00007

Melecký, L. (2015), Assesment of socio-economic development of Visegrad Four NUTS 2 Regions Using Composite Indices, Proceedings of 12th International Scientific Conference on Economic Policy in the European Union Member Countries, Opava: Silesian University Opava, pp. 561-571.

Melecký, L. and Poledníková, E. (2012), Use of Multivariate Methods for Disparities Evaluation in Visegrad Four Countries in Comparison with Germany and Austria, Proceedings of $1^{\text {st }}$ International Conference on European Integration, Ostrava: VŠBTU Ostrava, pp. 199-210.

Melecký, L. and Staníčková, M. (2015), Assessment of EU Regional Resilience Using Composite Index, Proceedings of $13^{\text {th }}$ International Scientific Conference Economic Policy in the European Union Member Countries, Ostrava: VŠB-TU Ostrava, pp. 382-395.

Meszaros, E.L. and Țoca, C.V. (2020), The EU's multifaceted approach to resilience building in the Eastern Neighbourhood. Security sector reform in Ukraine, Eastern Journal of European Studies, 11(SI), pp. 120-145.

Miller, K.K., Johnson, A. and Dabson, B. (2016), Measuring Resilience and Vulnerability in US Counties, Working paper, No. 7, Harry S. Truman School of Public Affairs (retrieved from https://truman.missouri.edu/institute-public-policy/publication/ working-paper-ipp07-1-measuring-resilience-and-vulnerability-us).

Modica, M., Reggiani, A. and Nijkamp, P. (2018), Vulnerability, resilience and exposure: methodological aspects and an empirical applicationsto shocks, SEEDS Working Papers 1318, SEEDS, Sustainability Environmental Economics and Dynamics Studies. 
Norris, F.H., Stevens, S.P., Pfefferbaum, B., Wyche, K.F. and Pfefferbaum, R.L. (2008), Community resilience as a metaphor, theory, set of capacities, and strategy for disaster readiness, American Journal of Community Psychology, 41(1-2), pp. 127-150. https://doi.org/10.1007/s10464-007-9156-6

OECD (2018), OECD Science, Technology and Innovation Outlook 2018: Adapting to Technological and Societal Disruption, Paris: OECD Publishing.

OECD (2019), Regions in Industrial Transition: Policies for People and Places, Paris: OECD Publishing.

OECD (2020a), Cities Policy Responses (retrieved from https://www.oecd.org/coronavirus/ policy-responses/cities-policy-re-sponses-fd1053ff/).

OECD (2020b), The Territorial Impact of COVID-19: Managing the Crisis across Levels of Government. Paris: OECD Publishing (retrieved from https://www.oecd.org/ coronavirus/policy-responses/the-territorial-impact-of-covid-19-managing-thecrisis-across-levels-of-government-d3e314e1/).

Palekienea, O., Vicieneb, Z.S. and Bruneckienec, J. (2015), The application of resilience concept in the regional development context, Procedia - Social and Behavioral Sciences, 213(1), pp. 179-184.

Paré, G. and Kitsiou, S. (2016), Evaluation Methods for Literature Researchs, in: Lau F. and Kuziemsky C. (eds.), Handbookof eHealth, Canada: British Columbia, pp. 57-179.

Paton, D. and Johnston, D. (2001), Disaster and Communities: Vulnerability, Resilience, and Preparedness, Disaster Prevention and Management, 10(4), pp. 270-277. https://doi.org/10.1108/EUM0000000005930

Pavlík, A. (2016), Odolnost českých nemetropolitních regionů. Výzkumměst a nemetropolitníc hregionů, Výročni konference České geografické společnosti, České Budějovice: Jihočeská univerzita v Českých Budějovicích, pp. 204-216.

Psycharis, Y., Kallioras, D. and Pantazis, P. (2014), Economic crisis and regional resilience: detecting the 'geographical footprint'of economic crisis in Greece, Regional Science Policy \& Practice, 6(2), pp. 121-141. https://doi.org/10.1111/rsp3.12032

Rakotomanjaka, J. (2014), The Development of Economic and Environmental Vulnerability and Resilience Indicators for Small Island Developing States. An overview of four island states of the Indian Ocean: Comoros, Madagascar, Mauritius and Seychelles.

Randa, M. (2013), Regional Specialisation and Economic Volatility of Czech Regions, Prague: Charles University, Faculty of Science, Department of Social Geography and Region.

Renschler, C.S., Frazier, A.E., Arendt, L.A., Cimellaro, G.P., Reinhorn, A.M. and Bruneau, M. (2010), Developing the 'PEOPLES'resilience framework for defining and measuring disaster resilience at the community scale, $9^{\text {th }}$ US National and $10^{\text {th }}$ Canadian Conference on Earthquake Engineering 2010, Including Papers from the $4^{\text {th }}$ International Tsunami Symposium, 2, pp. 1152-1161.

Romanova, T. (2020), The Concept of EU Resilience in the Pandemic Era (retrieved from https://valdaiclub.com/a/highlights/the-concept-of-resilience-of-the-europeanunion/). 
Rose, A. (2004), Defining and Measuring Economic Resilience to Disasters, Disaster Prevention and Management, 13(4), pp. 307-314. https://doi.org/10.1108/09653560410556528

Rose, A. (2009), Economic Resilience to Disasters, Research Report 8, Washington: Community and Regional Resilience Institute (retieved from https://s31207.pcdn.co/wp-content/uploads/2019/09/Economic-Resilience-toDisasters.pdf).

Rose, A. and Krausmann, E. (2013), An economic framework for the development of a resilience index for business recovery, International Journal of Disaster Risk Reduction, 5, pp. 73-83. https://doi.org/10.1016/j.ijdrr.2013.08.003

Rose, A. and Liao, S.Y. (2005), Modelling regional economic resilience to disasters: a computable general equilibrium model of water service disruptions, Journal of Regional Science, 45(1), pp. 75-112. https://doi.org/10.1111/j.0022$\underline{4146.2005 .00365 . x}$

Salvati, L., Carlucci, M. and Venanzoni, G. (2017), Recession, resilience, local labour markets: wealthier is better?, Letters in Spatial and Resource Sciences, 10(2), pp. 177-204. https://doi.org/10.1007/s12076-016-0180-8

Simmie, J. and Martin, R. (2010), The economic resilience of regions: towards an evolutionary approach, Cambridge Journal of Regions, Economy and Society, 3(1), pp. 27-43. https://doi.org/10.1093/cjres/rsp029

Slach, O. (2013), Profilace měkkých faktorů regionálnícho rozvoje, Ostrava: ACCENDO o.p.s., 2013.

Snyder, H. (2019), Literature research as a research methodology: An overview and guidelines, Journal of Business Research, 104, pp. 333-339. https://doi.org/10.1016/j.jbusres.2019.07.039

Staníčková, M. (2017a), Creation of Composite Index of the EU Regional Resilience: Analysis and Selection of Indicators, Proceedings of the 13th International Conference Liberec Economic Forum 2017, pp. 136-144.

Staníčková, M. (2017b), Concept of resilience in the context of regional development: systematic literature research of theory and realistic aspects, 20th International Colloquium on Regional Sciences, Conference Proceedings, pp. 67-74.

Staníčková, M. and Melecký, L. (2018), Boosting the EU Competitiveness as Response to Economic Shocks, in: Ushakov, D. (eds.), Economic Reforms for Global Competitiveness, Pennsylvania: IGI Global, pp. 241-264.

Staníčková, M. and Melecký, L. (2018), Understanding of resilience in the context of regional development using composite index approach: the case of European Union NUTS-2 regions, Regional Studies, Regional Science, 5(1), pp. 231-254.

Svoboda, O. (2013a), Koncept regionální odolnosti v context uhospodářské krize, Regionální rozvoj mez iteorií a praxí IV, Obyvatelstvo, region a bezpečnost, Pardubice: Univerzita Pardubice, pp. 54-60.

Svoboda, O. (2013b), Ekonomická odolnost regioni̊, Pardubice: Univerzita Pardubice. Fakulta ekonomicko-správní, Ústavregionálních a bezpečnostníchvěd. 
UNESCO (2020), Urban Solutions: Learning from Cities' Responses to COVID-19 (retrieved from https://en.unesco.org/urban-solu-tions-Learning-from-citiesresponses-to-COVID19).

Weir, M., Pindus, N., WiaL, H. and Wolman, H. (2012), Urban and Regional Policy and Its Effects: Building Resilient Regions, Washington: Brookings Institution Press.

Ženka, J. and Slach, O. (2018), Ekonomická odolnost starých českých průmyslových regionů, XXI Mezinárodní kolokvium o regionálních vědách, Kurdějov: Masarykova univerzita, pp. 20-27. 


\section{Appendix}

Table 1. Czech authors focusing on dimensions of resilience after the 2007-2008 economic crisis until nowadays

\begin{tabular}{|c|c|c|}
\hline Year & Author/s & Dimensions of resilience \\
\hline 2012 & $\begin{array}{l}\text { KOUTSKÝ, J. } \\
\text { E.T AL. }\end{array}$ & $\begin{array}{l}\text { main economic indicators: GDP, investment, fixed } \\
\text { capital formation, regional labour market: employment, } \\
\text { unemployment and derived indicators, indicators of } \\
\text { evaluation of soft factors: quality of local public } \\
\text { administration, quality of the local business } \\
\text { environment, quality of life of the population }\end{array}$ \\
\hline 2013a & SVOBODA, O. & $\begin{array}{l}\text { economic performance of the region, the structure of } \\
\text { economic activities of the region, innovation activity } \\
\text { and activity of the region in the field of R\&D, quality of } \\
\text { human capital, characteristics of the labour market and } \\
\text { demographic parameters of the region }\end{array}$ \\
\hline 2013 & HLAVÁČEK, P. & $\begin{array}{l}\text { gross off unemployment in } \mathrm{R} \& \mathrm{D} \text {, increase of expenses } \\
\text { for } \mathrm{R} \& \mathrm{D} \text {, growth and number of innovation business, } \\
\text { increase of number of persons with a University degree }\end{array}$ \\
\hline 2013b & SVOBODA, O. & $\begin{array}{l}\text { dynamic growth of the region, the structure of the } \\
\text { economy, export orientation and specialisation of the } \\
\text { region, human capital, innovation rate, business and } \\
\text { corporate culture, location of the region, institutional } \\
\text { arrangement of the region }\end{array}$ \\
\hline 2013 & RANDA, M. & $\begin{array}{l}\text { year-on-year change in employment growth indicators } \\
\text { during the economic crisis in } 2008 \text { to } 2009 \text {, GDP / } \\
\text { person, the willingness of companies to change with } \\
\text { changing economic conditions }\end{array}$ \\
\hline 2013 & SLACH, O. & $\begin{array}{l}\text { labour market, business environment and infrastructure, } \\
\text { prices, costs, incomes, markets, economic ties, } \\
\text { cooperation networks, geographical location of the city, } \\
\text { flexibility, mentality, activity, economic climate, image, } \\
\text { tradition, culture, landscape quality, cities, housing, } \\
\text { sport leisure time, infrastructure, environmental quality }\end{array}$ \\
\hline 2016 & PAVLÍK, A. & $\begin{array}{l}\text { economic performance, specialisation of the region, } \\
\text { investment activity, company structure, population size, } \\
\text { quality of human capital, labour market, growth during } \\
\text { the boom period, vulnerability in times of crisis }\end{array}$ \\
\hline 2017b & STANÍČKOVÁ, M. & $\begin{array}{l}\text { community links, human capital, socio-demographic } \\
\text { structure, labour market, economic performance, } \\
\text { innovation, science and research }\end{array}$ \\
\hline 2017a & STANÍČKOVÁ, M. & $\begin{array}{l}\text { macroeconomic capacity, microeconomic capacity, } \\
\text { labour market capacity, socio-demographic capacity, }\end{array}$ \\
\hline
\end{tabular}




\begin{tabular}{|c|c|c|}
\hline & & $\begin{array}{l}\text { health capacity, education capacity, infrastructure and } \\
\text { connectivity capacity, innovation and research capacity }\end{array}$ \\
\hline 2018 & $\begin{array}{l}\text { ŽENKA, J., } \\
\text { SLACH, O. }\end{array}$ & $\begin{array}{l}\text { employment stability / volatility, recovery (growth of } \\
\text { economic performance compared to other regions) and } \\
\text { reorientation (intensity of changes in the sectoral } \\
\text { structure of employment) }\end{array}$ \\
\hline 2018 & $\begin{array}{l}\text { STANÍČOVÁ, } \\
\text { MELECKÝ, L. }\end{array}$ & $\begin{array}{l}\text { human capital, socio-demographic structure, labour } \\
\text { market, economic performance, innovation, science and } \\
\text { research }\end{array}$ \\
\hline
\end{tabular}

Source: Author's own elaboration, 2020

Table 2. Worldwide authors focusing on dimensions of resilience from the 20072008 global economic crisis until 2013

\begin{tabular}{|c|c|c|}
\hline Year & Author/s & Dimensions of resilience \\
\hline 2006 & FOSTER, K.A & $\begin{array}{l}\text { regional economic capacity, socio-demographic } \\
\text { capacity of region and regional community capacity }\end{array}$ \\
\hline 2008 & HILL, E. et al. & $\begin{array}{l}\text { governance responses, public-private collaborative } \\
\text { efforts, private sector efforts organised on a public } \\
\text { level; industry or firm responses by firms or industries } \\
\text { in the region; institutional characteristics that } \\
\text { condition, constrain, or promote effective action to } \\
\text { respond to economic shocks }\end{array}$ \\
\hline 2008 & CUTTER L.S. et al. & $\begin{array}{l}\text { race and ethnicity, age, socio-economic status, gender, } \\
\text { employment, education, household structure, access to } \\
\text { services, occupation, housing, special needs }\end{array}$ \\
\hline 2009 & EKOSGEN & $\begin{array}{l}\text { sectoral mix, the workforce, enterprise, labour market, } \\
\text { economic dynamism }\end{array}$ \\
\hline 2009 & $\begin{array}{l}\text { EKOSGEN, } \\
\text { EDAW/AECOM }\end{array}$ & $\begin{array}{l}\text { sectoral mix, the workforce, enterprise, labour market, } \\
\text { assets and infrastructure, scale and proximity }\end{array}$ \\
\hline 2009 & BRIGUGLIO, L. & $\begin{array}{l}\text { macroeconomic stability, microeconomic market } \\
\text { efficiency, good governance, and social development }\end{array}$ \\
\hline 2010 & $\begin{array}{l}\text { CHRISTOPHERSON } \\
\text { et al. }\end{array}$ & $\begin{array}{l}\text { past and current economic growth, evaluation } \\
\text { additionally adaptation to changes, convergence, and } \\
\text { sustainability }\end{array}$ \\
\hline 2010 & $\begin{array}{l}\text { RENSCHLER, C. et } \\
\text { al. }\end{array}$ & $\begin{array}{l}\text { population and } \\
\text { environmental/ecosystem, organised governmental } \\
\text { services, physical infrastructure, lifestyle and } \\
\text { community competence, economic development, and } \\
\text { social-cultural capital }\end{array}$ \\
\hline 2011 & $\begin{array}{l}\text { ECONOMIC } \\
\text { COMMISSION FOR } \\
\text { LATIN AMERICA } \\
\text { AND THE } \\
\text { CARIBBEAN }\end{array}$ & $\begin{array}{l}\text { macroeconomic stability, microeconomic market } \\
\text { efficiency, good governance, social development }\end{array}$ \\
\hline
\end{tabular}


2012 MARTIN, R.

dynamic growth of region, structure of the economy, export orientation and specialisation of region, human capital, innovation rate, business and corporate culture, localisation of region, and institutional arrangement in region

\begin{tabular}{|c|c|c|}
\hline 2012 & DABSON, B. et al. & infrastructure, economic, social \\
\hline 2012 & $\begin{array}{l}\text { ANURADHA, S. } \\
\text { AND RAGAB, A. }\end{array}$ & $\begin{array}{l}\text { macroeconomic stability, microeconomic market } \\
\text { efficiency, good governance, social development }\end{array}$ \\
\hline 2012 & MANCINI, A. et al. & $\begin{array}{l}\text { economic resiliency, social and cultural diversity } \\
\text { (population size, human skills mix) and civic } \\
\text { infrastructure }\end{array}$ \\
\hline
\end{tabular}

2013 GRAZIANO, P. Economic, social and environmental

Source: Authors' representation, 2020

Table 3. Worldwide authors focusing on dimensions of resilience from 2014 until nowadays

\begin{tabular}{|c|c|c|}
\hline Year & Author/s & Dimensions of resilience \\
\hline 2014 & $\begin{array}{l}\text { RAKOTOMANJAK } \\
\text { A, J. }\end{array}$ & $\begin{array}{l}\text { macroeconomic stability, market efficiency, good } \\
\text { political governance, social development }\end{array}$ \\
\hline 2014 & PSYCHARIS, Y. & $\begin{array}{l}\text { socio-demographic environment, economic } \\
\text { environment, citizens' welfare, regional policy }\end{array}$ \\
\hline 2015 & PALEKIENEA et al. & $\begin{array}{l}\text { economic structure, innovation system, skills base, } \\
\text { competitiveness level prior to shock, mix of actions } \\
\text { and decisions for accelerating regional resumption }\end{array}$ \\
\hline 2015 & KAHSAI, M. et al. & $\begin{array}{l}\text { Industrial diversity, income diversity, entrepreneurial } \\
\text { activity and business dynamics, human and social } \\
\text { capital, scale and proximity, physical capital } \\
\text { (infrastructure) }\end{array}$ \\
\hline 2016 & MARTIN, R. et al. & $\begin{array}{l}\text { industrial and business structure, financial } \\
\text { arrangements, agency and decision-making, labour } \\
\text { market conditions, government arrangements }\end{array}$ \\
\hline 2016 & SALVATI, L. & $\begin{array}{l}\text { territory, land use, settlements, district specialisation, } \\
\text { economic performances, economic structure, } \\
\text { education, demography and population structure }\end{array}$ \\
\hline 2016 & $\begin{array}{l}\text { ASIAN } \\
\text { DEVELOPMENT } \\
\text { BANK }\end{array}$ & $\begin{array}{l}\text { macroeconomic policy, microeconomic policy, } \\
\text { structural reform policy, global and regional } \\
\text { cooperation, governance and institutions }\end{array}$ \\
\hline 2016 & MILLER, K. & $\begin{array}{l}\text { social, infrastructure, economic, and environmental } \\
\text { dimensions }\end{array}$ \\
\hline 2016 & $\begin{array}{l}\text { CALDERA- } \\
\text { SÁNCHEZ, A. }\end{array}$ & $\begin{array}{l}\text { quality of institutions, product market policies, labour } \\
\text { market policies }\end{array}$ \\
\hline 2016 & FAO & $\begin{array}{l}\text { access to basic services (schools, health centres, water, } \\
\text { electricity and nearby markets) assets; social safety } \\
\text { nets; sensitivity; adaptive capacity. }\end{array}$ \\
\hline
\end{tabular}




\begin{tabular}{|c|c|c|}
\hline 2018 & $\begin{array}{l}\text { GIANMOENA, L. } \\
\text { RIOS, V. }\end{array}$ & $\begin{array}{l}\text { institutional factors, knowledge and innovation system } \\
\text { factors, socio-demographic factors, labour market } \\
\text { factors, labour market institutions }\end{array}$ \\
\hline 2018 & MODICA, M. et al. & $\begin{array}{l}\text { agricultural, business, demographic, economic, } \\
\text { institutional, land, material, natural, risk, social, social } \\
\text { capital }\end{array}$ \\
\hline 2018 & $\begin{array}{l}\text { FRATESI, U., } \\
\text { PERUCCA, G. }\end{array}$ & $\begin{array}{l}\text { accessibility, collective goods, human capital, private } \\
\text { capital, behavioural modes, private relational services, } \\
\text { agglomeration economies }\end{array}$ \\
\hline 2018 & $\begin{array}{l}\text { BRUNECKIENE, J. } \\
\text { et al. }\end{array}$ & $\begin{array}{l}\text { factors of the insight capacity group, factors of the } \\
\text { regional governance capacity group, factors of the } \\
\text { knowledge and innovation capacity group, factors of } \\
\text { the learning capacity group, factors of the networking } \\
\text { and cooperation capacity group, factors of the regional } \\
\text { infrastructure }\end{array}$ \\
\hline 2019 & $\begin{array}{l}\text { GIACOMETTI, A., } \\
\text { TERÄS, J. }\end{array}$ & financial, human, natural, physical, political, social \\
\hline 2020 & $\begin{array}{l}\text { CHACON- } \\
\text { HURTADO, } \\
\text { et al. }\end{array}$ & $\begin{array}{l}\text { human capital, industrial diversity, entrepreneurship, } \\
\text { liability, macroeconomic conditions, social capital, } \\
\text { infrastructure }\end{array}$ \\
\hline $2020 b$ & $\begin{array}{l}\text { EUROPEAN } \\
\text { COMMISSION }\end{array}$ & $\begin{array}{l}\text { connectivity, human capital, use of internet, } \\
\text { integration of digital technology, digital public } \\
\text { services }\end{array}$ \\
\hline $2020 a$ & $\begin{array}{l}\text { EUROPEAN } \\
\text { COMMISSION }\end{array}$ & $\begin{array}{l}\text { social and economic dimension, geopolitical } \\
\text { dimension, green dimension, digital dimension }\end{array}$ \\
\hline
\end{tabular}

Source: Authors' representation, 2020 